\title{
Morphological variation of Libyan carob (Ceratonia siliqua L.)
}

\author{
Ezzudin S. M. Ali ${ }^{1 *}$, Hesaien M. Mustafa ${ }^{2}$ Khansa A. Omar Blkasem $^{2}$ \\ ${ }^{1}$ Faculty of Agriculture, Omar Al-Mukhtar University, Libya \\ ${ }^{2}$ Faculty of Natural Resources, Omar Al-Mukhtar University, Libya
}

Received: 18 June 2019/ Accepted: 30 June 2019

Doi: https://doi.org/10.54172/mjsc.v34i2.77

\begin{abstract}
Carob tree (Ceratonia siliqua L., $2 \mathrm{n}=24$ ) is an evergreen endemic species found naturally in El-Jabal El-Akhdar region which is located immediately south of the coastal belt in the northeastern region of Libya. Morphological characteristics have been the main descriptive tool to characterize a given collection or germplasm, or to identify and differentiate wild type populations. Eighteen carob population were collected from six different sites in El-Jabal El-Akhdar area. Seven characters on discriminative pods were measured: the length, width, thickness, number of seeds, weight of pulp, and yield as well as one character to seeds: the weight seeds. The present study showed that the choice of pod characters to assess Libyan carob diversity is a useful and powerful tool. The means and standard deviations of morphometric characters measured in Libyan carob showed highly significant differences among the studied populations for all the examined characteristics. Differences in morphometric traits of carob pods and seeds among Libyan carob populations are primarily caused by genetic factors. The pod size of Libyan carob is considered to be the medium size $(10.89-17.55 \mathrm{~cm})$.
\end{abstract}

Key words: Carob, Ceratonia siliqua, morphological traits, genetic variation.

\section{INTRODUCTION}

The carob tree is a slowly growing, woody evergreen, sclerophyll, and widespread species occurring as a native plant in the Mediterranean Basin (Ramón-Laca \& Mabberley, 2004). It has been grown since antiquity in most countries of the Mediterranean basin, usually in mild and dry places with poor soils. Its value was recognized by the ancient Greeks, who brought it from its native Middle East to Greece and Italy and by the Arabs, who disseminated it along the North African coast and north into Spain and Portugal. It was spread in recent times to other Mediterranean-like regions such as California, Arizona, Mexico, Chile and Argentina by Spaniards, to parts of Australia by Mediterranean emigrants and to South Africa and India by the English (Battle \& Tous, 1997).

The carob tree (Ceratonia siliqua L. $2 \mathrm{n}=24$ ) is an angiosperm, dicotyledonous belonging to the order Rosales, family Fabaceae (Srečec et al., 2016). It tolerates drought explaining its large distribution in the arid and semi-arid Mediterranean climate (Correia \& MartinsLoucao, 1994; Lo Gullo \& Salleo, 1988). Whose origin seems to be the eastern Mediterranean has been domesticated since 4000 $\mathrm{BC}$, and his extensive dates from at least $2000 \mathrm{BC}$ culture, its longevity is considerable (up to 200 years), and it can reach up to fifteen meters high. It is formerly operated in particular through its feed and food qualities. Thus the tree is useful in human and animal food (El Kahkahi, Zouhair, Ait Chitt, \& Errakhi, 2014).

The carob tree is an important component of the Mediterranean vegetation. Traditionally, carob pods with their sugary pulp are a staple in the diet of farm animals and are eaten by children as snacks or by people in times of 
famine. However, currently, the main interest is seed production for gum extraction. Furthermore, Carob is well known in the Mediterranean countries for its ornamental, nutritional, and medicinal value (Batista, Amaral, \& Proença Da Cunha, 1996; Battle \& Tous, 1997). Carob pods were also used in ancient Egypt, where the pulp of the pods was mixed in porridge, with little honey and wax, as a treatment for diarrhea and some other diseases. The trees are also useful as ornamentals, landscaping, windbreaks, and in aforestation. Cattle can browse on leaves, and the wood is suitable for fuel (Kahkah, Zouhair, Diouri, Ait Chitt, \& Errakhi, 2015).

Phenotypic characteristics have been and continue to be used as essential components in the final classification of living organisms. Till today, morphological characteristics have been the main descriptive tool to characterize a given collection or germplasm and to identify and differentiate wild type populations (Tous, Romero, Plana, \& Batlle, 1996). Morphological characters of pods and seeds were widely used as quantitative markers to identify the variation of carob according to certain criteria in several wild populations and collections (Garbgallom et al., 1997; Barracosa, Osorio, \& Cravador, 2007; Sidina et al., 2009). Morphological traits of pods and seeds show a very high diversity in the population of Tunisian carob; type and geographical origin of the trees are considered as the source of the variation (Naghmouchi, Khouja, Romero, Tous, \& Boussaid, 2009). In Spain, (Albanell, Caja, \& Plaixats, 1991) found a high diversity in morphological parameters of pods and seeds. Forty seven Moroccan carob populations from different sites were studied to assess their genetic variation based on pods and kernels measures. Most of the parameters measured showed a significant difference that indicates a high genetic diversity (El Kahkahi et al., 2014; Elfazazi, Jbilou, Assaidi, Benbati, \& Harrak, 2017).
In Libya, the carob tree is found naturally in El-Jabal El-Akhdar area which is located immediately south of the coastal belt in the northeastern region of the country. El-Jabal El-Akhdar extends on the coast belt to about $300 \mathrm{~km}$ and rises to about $881 \mathrm{~m}$ above sea level. It is generally rocky and stony, and intersected frequently by many valleys. The average rainfall ranges between 250-600 mm, and the soils are terra-rossa or heavy clay (Johnson, 1973; Sharaf, 1971; El-Zwaam, 1995). The carob trees are scattered in the area of El-Jabal El-Akhdar in association with many wild species such as olive (Olea europaea), mastic (Pistacia lentiscus) and juniper (Junipurus phoenicea).

The objective of the present study was to evaluate the morphological characterization of the fruit of carob tree, and to establish correlations between different morphological parameters of the Libyan carob.

\section{MATERIALS AND METHODS}

Plant material: The plant material consists of pods of carob tree. It was collected from six different locations in El-Jabal El-Akhdar (Table 1). So we brought in the samples to the laboratory. Thirty pods were taken randomly from each site, and seven characters on discriminative pods were measured to know the length, width, thickness, number of seeds, weight of pulp, and yield (seeds weight/ pod weight $\times 100)$, as well as one character to seeds: the weight seeds. 
Table (1). Sites of the examined carob populations

\begin{tabular}{|c|c|c|c|c|c|}
\hline Population & Region & Latitude $\mathrm{N}$ & Longitude W & Altitude(m) & Rainfall (mm) \\
\hline $\mathrm{P} 1$ & Al Haniyah & $32^{\circ} 83^{\prime} .99^{\prime \prime}$ & $0^{\circ} 21^{\prime} 53^{\prime \prime}$ & 280 & 270 \\
\hline $\mathrm{P} 2$ & Al Haniyah & $32^{\circ} 83^{\prime} .99^{\prime \prime}$ & $0^{\circ} 21^{\prime} 53^{\prime \prime}$ & 280 & 270 \\
\hline P3 & Al Haniyah & $32^{\circ} 83^{\prime} .99^{\prime \prime}$ & $0^{\circ} 21^{\prime} 53^{\prime \prime}$ & 280 & 270 \\
\hline $\mathrm{P} 4$ & Al Waseta & $32^{\circ} 52^{\prime} .79^{\prime \prime}$ & $0^{\circ} 21^{\prime} 43^{\prime \prime}$ & 248 & 270 \\
\hline P5 & Al Waseta & $32^{\circ} 52^{\prime} .82^{\prime \prime}$ & $0^{\circ} 21^{\prime} 43^{\prime \prime}$ & 252 & 270 \\
\hline P6 & Al Waseta & $32^{\circ} 52^{\prime} .82^{\prime \prime}$ & $0^{\circ} 21^{\prime} 43^{\prime \prime}$ & 252 & 270 \\
\hline $\mathrm{P} 7$ & Zawiatalargwb & $32^{\circ} 83^{\prime} .53^{\prime \prime}$ & $0^{\circ} 21^{\prime} 60^{\prime \prime}$ & 280 & 236 \\
\hline P8 & Zawiatalargwb & $32^{\circ} 83^{\prime} .53^{\prime \prime}$ & $0^{\circ} 21^{\prime} 60^{\prime \prime}$ & 280 & 236 \\
\hline P9 & Zawiatalargwb & $32^{\circ} 83^{\prime} .53^{\prime \prime}$ & $0^{\circ} 21^{\prime} 60^{\prime \prime}$ & 280 & 236 \\
\hline $\mathrm{P} 10$ & Albaqara & $32^{\circ} 79^{\prime} .39^{\prime \prime}$ & $0^{\circ} 21^{\prime} 84^{\prime \prime}$ & 280 & 236 \\
\hline $\mathrm{P} 11$ & Albaqara & $32^{\circ} 79^{\prime} .39^{\prime \prime}$ & $0^{\circ} 21^{\prime} 84^{\prime \prime}$ & 280 & 236 \\
\hline $\mathrm{P} 12$ & Albaqara & $32^{\circ} 79^{\prime} .39^{\prime \prime}$ & $0^{\circ} 21^{\prime} 84^{\prime \prime}$ & 280 & 236 \\
\hline $\mathrm{P} 13$ & Al Faedea & $32^{\circ} 36^{\prime} .43^{\prime \prime}$ & $0^{\circ} 21^{\prime} 56^{\prime \prime}$ & 780 & 236 \\
\hline $\mathrm{P} 14$ & Al Faedea & $32^{\circ} 36^{\prime} .43^{\prime \prime}$ & $0^{\circ} 21^{\prime} 56^{\prime \prime}$ & 780 & 236 \\
\hline P15 & Al Faedea & $32^{\circ} 36^{\prime} .45^{\prime \prime}$ & $0^{\circ} 21^{\prime} 56^{\prime \prime}$ & 787 & 236 \\
\hline $\mathrm{P} 16$ & Sadi M. Alhamry & $32^{\circ} 38^{\prime} .38^{\prime \prime}$ & $0^{\circ} 21^{\prime} 50^{\prime \prime}$ & 841 & 650 \\
\hline $\mathrm{P} 17$ & Sadi M. Alhamry & $32^{\circ} 36^{\prime} .52^{\prime \prime}$ & $0^{\circ} 21^{\prime} 54^{\prime \prime}$ & 795 & 650 \\
\hline P18 & Sadi M. Alhamry & $32^{\circ} 36^{\prime} .52^{\prime \prime}$ & $0^{\circ} 21^{\prime} 56^{\prime \prime}$ & 795 & 650 \\
\hline
\end{tabular}

Data analysis: The numerical values obtained from various parameters measured were analyzed by Minitab software to calculate averages and standard deviations, which facilitated the comparison of fruit trees together along with each character. Furthermore, correlation between different studied morphological parameters was evaluated using Pearson correlation coefficient.

\section{RESULTS}

The means and standard deviation values of all morphological characters in the studied Libyan carob populations (accessions) are reported in table 2. At the outset, we can note that the results showed highly significant differences among the populations (accessions) for all the examined morphological characters.

The sizes of carob pods are variable from one population to another. The pod length varies between $10.89 \pm 3.10 \mathrm{~cm}$ for population 16 to
$17.55 \pm 2.94 \mathrm{~cm}$ for population 14 , and the width varies between $1.23 \pm 0.11 \mathrm{~cm}$ for population 6 to $1.63 \pm 0.28 \mathrm{~cm}$ for population 11 . The pod thickness varies between $0.45 \pm 0.7 \mathrm{~cm}$ for population 7 to $0.87 \pm 0.12 \mathrm{~cm}$ for population 12 , the pod weight varies between $8.87 \pm 1.75 \mathrm{~g}$ for population 4 to $16.06 \pm 5.56 \mathrm{~g}$ for population 12.

Moreover, the morphological characteristics of the seed (kernel) are also varied among the examined populations. The seeds number per pod varies from $6.80 \pm 3.43$ for population 3 to $12.90 \pm 2.03$ for population 11 and seed weight varies from $1.07 \pm 0.4 \mathrm{~g}$ for population 16 to $2.44 \pm 0.29 \mathrm{~g}$ for population 8 .

Values corresponding to the yield $\%$ and pulp weight varies respectively $(11.05 \pm 3.71 \%$ for population 17 to $23.25 \pm 8.26 \%$ for population 15 , and $7.39 \pm 1.65 \mathrm{~g}$ to $14.66 \pm 5.33$ for population 13). 
Table 2: Morphological traits of Libyan carob (Ceratonia siliqua L.) populations

\begin{tabular}{ccccccccc}
\hline \hline & $\begin{array}{c}\text { Pod } \\
\text { Length } \\
\text { cm }\end{array}$ & $\begin{array}{c}\text { Pod } \\
\text { Width }\end{array}$ & $\begin{array}{c}\text { Pod } \\
\text { Thickness } \\
\text { cm }\end{array}$ & $\begin{array}{c}\text { Poight } \\
\text { g }\end{array}$ & $\begin{array}{c}\text { Seeds } \\
\text { Number }\end{array}$ & $\begin{array}{c}\text { Seeds } \\
\text { Weight }\end{array}$ & Yield \% & $\begin{array}{c}\text { Pulp } \\
\text { Weight } \\
\text { g }\end{array}$ \\
\cline { 2 - 9 } P1 & $11.99 \pm 4.69$ & $1.42 \pm 0.12$ & $0.52 \pm 0.07$ & $9.20 \pm 1.37$ & $10.10 \pm 1.66$ & $1.90 \pm 0.27$ & $20.77 \pm 3.99$ & $7.39 \pm 1.33$ \\
P2 & $16.65 \pm 2.93$ & $1.62 \pm 0.15$ & $0.48 \pm 0.04$ & $12.54 \pm 1.69$ & $12.00 \pm 1.83$ & $2.27 \pm 0.27$ & $18.36 \pm 2.97$ & $10.27 \pm 1.65$ \\
P3 & $13.88 \pm 1.57$ & $1.43 \pm 0.13$ & $0.57 \pm 0.06$ & $10.39 \pm 2.23$ & $6.80 \pm 3.43$ & $1.28 \pm 0.68$ & $12.12 \pm 4.74$ & $9.11 \pm 1.77$ \\
P4 & $16.30 \pm 2.61$ & $1.39 \pm 0.18$ & $0.60 \pm 0.06$ & $8.87 \pm 1.75$ & $10.60 \pm 2.07$ & $1.38 \pm 0.29$ & $16.57 \pm 2.69$ & $7.39 \pm 1.67$ \\
P5 & $16.70 \pm 1.91$ & $1.44 \pm 0.12$ & $0.47 \pm 0.05$ & $9.27 \pm 1.62$ & $11.70 \pm 2.71$ & $2.14 \pm 0.49$ & $22.95 \pm 2.42$ & $7.13 \pm 1.18$ \\
P6 & $16.15 \pm 1.82$ & $1.23 \pm 0.11$ & $0.49 \pm 0.08$ & $14.22 \pm 3.14$ & $11.40 \pm 2.50$ & $1.99 \pm 0.53$ & $14.34 \pm 3.98$ & $12.23 \pm 2.94$ \\
P7 & $16.10 \pm 2.20$ & $1.31 \pm 0.15$ & $0.45 \pm 0.07$ & $9.87 \pm 2.68$ & $9.10 \pm 2.77$ & $1.54 \pm 0.56$ & $15.63 \pm 3.94$ & $8.34 \pm 2.30$ \\
P8 & $16.20 \pm 2.37$ & $1.35 \pm 0.21$ & $0.48 \pm 0.06$ & $10.63 \pm 0.95$ & $11.50 \pm 1.84$ & $2.44 \pm 0.29$ & $22.96 \pm 2.21$ & $8.19 \pm 0.79$ \\
P9 & $15.90 \pm 2.30$ & $1.41 \pm 0.11$ & $0.61 \pm 0.05$ & $11.93 \pm 2.87$ & $11.00 \pm 2.63$ & $2.28 \pm 0.68$ & $18.93 \pm 2.43$ & $9.65 \pm 2.26$ \\
P10 & $13.35 \pm 1.49$ & $1.48 \pm 0.25$ & $0.47 \pm 0.09$ & $10.76 \pm 1.74$ & $10.80 \pm 2.70$ & $1.77 \pm 0.57$ & $16.67 \pm 5.43$ & $8.99 \pm 1.68$ \\
P11 & $13.62 \pm 1.18$ & $1.63 \pm 0.28$ & $0.52 \pm 0.08$ & $9.22 \pm 2.33$ & $12.90 \pm 2.03$ & $1.96 \pm 0.53$ & $21.66 \pm 4.61$ & $7.26 \pm 2.01$ \\
P12 & $15.71 \pm 1.33$ & $1.50 \pm 0.20$ & $0.66 \pm 0.12$ & $12.09 \pm 2.47$ & $12.50 \pm 2.17$ & $2.05 \pm 0.47$ & $17.30 \pm 3.98$ & $10.03 \pm 2.34$ \\
P13 & $14.75 \pm 2.95$ & $1.61 \pm 0.19$ & $0.52 \pm 0.10$ & $16.06 \pm 5.56$ & $10.80 \pm 3.36$ & $1.40 \pm 0.51$ & $9.08 \pm 2.76$ & $14.66 \pm 5.33$ \\
P14 & $17.55 \pm 2.94$ & $1.49 \pm 0.08$ & $0.66 \pm 0.11$ & $15.65 \pm 4.53$ & $10.90 \pm 2.03$ & $1.53 \pm 0.34$ & $10.27 \pm 2.54$ & $14.12 \pm 4.34$ \\
P15 & $15.65 \pm 3.07$ & $1.44 \pm 0.15$ & $0.48 \pm 0.08$ & $9.73 \pm 2.54$ & $9.00 \pm 1.49$ & $2.14 \pm 0.56$ & $23.23 \pm 8.26$ & $7.59 \pm 2.54$ \\
P16 & $10.89 \pm 3.10$ & $1.43 \pm 0.27$ & $0.49 \pm 0.07$ & $9.12 \pm 3.45$ & $7.40 \pm 1.43$ & $1.07 \pm 0.41$ & $12.06 \pm 3.47$ & $8.05 \pm 3.20$ \\
P17 & $12.34 \pm 2.33$ & $1.30 \pm 0.23$ & $0.55 \pm 0.09$ & $13.03 \pm 3.08$ & $11.50 \pm 2.22$ & $1.39 \pm 0.48$ & $11.05 \pm 3.71$ & $11.64 \pm 3.02$ \\
P18 & $13.82 \pm 2.48$ & $1.60 \pm 0.27$ & $0.51 \pm 0.10$ & $14.42 \pm 4.20$ & $9.50 \pm 1.96$ & $1.38 \pm 0.29$ & $10.41 \pm 3.89$ & $13.04 \pm 4.12$ \\
LSD & 2.25 & 0.16 & 0.07 & 2.56 & 2.06 & 0.42 & 3.54 & 2.40 \\
\hline \hline
\end{tabular}

The correlation matrix among all studied morphological traits is summarized in table 3 . The pod length is correlated positively with the pod weight, seed weight, and pulp weight with respective linear regression coefficients of $r=0.267,0.220$ and 0.229 . Moreover, the pod length showed a low correlation with pod width and pod thickness $(r=0.184$ and 0.165$)$. On the other hand, the pod length has no correlation with seeds number and yield percent.

The pod width shows a positive low correlation with the pod thickness $(\mathrm{r}=0.171)$, pod weight $(\mathrm{r}=0.178)$, and pulp weight $(\mathrm{r}=0.139)$. In contrast, the pod thickness shows no correlation with seeds number, seed weight, and yield percentage.

The pod thickness is positively correlated with the pod weight $(\mathrm{r}=0.233)$ and pulp weight (0.243). Moreover, the pod thickness is negatively correlated with pod yield percentage $(r$
$=-0,193)$ and has no correlation with seed number and seed weight.

The pod weight is positively correlated with the seeds number, seed weight, and pulp weight with respective linear regression coefficients of $\mathrm{r}=0.365,0.201$ and 0.984 . Furthermore, the pod weight is negatively correlated with the yield percentage $(\mathrm{r}=-0.468)$.

Seeds number shows a high correlation with the seed weight $(r=0.742)$, yield percent (0.408), and pulp weight (0.246). Meanwhile, seeds number has a high correlation with yield percent $(\mathrm{r}=0.710)$ but has no correlation with pulp weight. According to table 3 , the yield percentage has a negative correlation with the pulp weight $(\mathrm{r}=-0.602)$. 
Table 3: Pearson coefficient correlation for morphological characters of fruits (pods and seeds) of Libyan carob.

\begin{tabular}{|c|c|c|c|c|c|c|c|c|}
\hline & $\begin{array}{l}\text { Pod } \\
\text { Length } \\
\mathrm{cm}\end{array}$ & $\begin{array}{l}\text { Pod } \\
\text { Width } \\
\mathrm{cm}\end{array}$ & $\begin{array}{l}\text { Pod } \\
\text { Thickness } \\
\mathrm{cm}\end{array}$ & $\begin{array}{l}\text { Pod } \\
\text { Weight } \\
\text { g }\end{array}$ & $\begin{array}{l}\text { Seeds } \\
\text { number }\end{array}$ & $\begin{array}{l}\text { Seeds } \\
\text { Weight } \\
\mathrm{g}\end{array}$ & Yield \% & $\begin{array}{l}\text { Pulp } \\
\text { Weight } \\
\text { g }\end{array}$ \\
\hline Pod Length $\mathrm{cm}$ & 1.000 & & & & & & & \\
\hline Pod Width $\mathrm{cm}$ & $0.184^{*}$ & 1.000 & & & & & & \\
\hline $\begin{array}{l}\text { Pod Thickness } \\
\mathrm{cm}\end{array}$ & $0.165^{*}$ & $0.171^{*}$ & 1.000 & & & & & \\
\hline Pod Weight g & $0.267^{* *}$ & $0.178^{*}$ & $0.233^{* *}$ & 1.000 & & & & \\
\hline Seeds number & 0.139 & 0.066 & 0.092 & $0.365^{* *}$ & 1.000 & & & \\
\hline Seeds Weight $g$ & 0.120 & -0.020 & -0.035 & $0.201^{* *}$ & $0.742^{* *}$ & 1.000 & & \\
\hline Yield \% & 0.028 & -0.137 & $-0.193^{* *}$ & $-0.468^{* *}$ & $0.408^{* *}$ & $0.710^{* *}$ & 1.000 & \\
\hline Pulp Weight g & $0.229^{* *}$ & $0.185^{*}$ & $0.243^{* *}$ & $0.849^{* *}$ & $0.246^{* *}$ & 0.033 & $-0.602^{* *}$ & 1.000 \\
\hline
\end{tabular}

\section{DISCUSSION}

The present study showed that the choice of pod characteristics to assess Libyan carob diversity is a useful and powerful tool. Several authors had resort to the use of pod characteristics to identify, label or to characterize different carob populations, collections, or germaplasms (Battle \& Tous, 1997; Gharnit, Et Mtili, Ennabili, \& Ennabili, 2001; Marakis, Kalaitzakis, \& Mitrakos, 1988; Tous et al., 1996). Moreover, morphological characters of pods and seeds are widely used as quantitative markers to identify populations of carob according to certain criteria such as productivity, resistance to disease, and environmental stress (Konaté, Filali-Maltouf, \& Berraho, 2007).

The means and standard deviations of morphometric characters measured in the Libyan carob showed highly significant differences among the studied populations for all the examined characters. In agreement with our results, many authors have confirmed that carob showed a high diversity in morphological parameters in Spanish (Albanell et al., 1991), Italian (Garbgallo et al., 1997), Portuguese (Barracosa et al., 2007),

Moroccan (Konaté et al., 2007), and Tunisian (C) 2019 The Author(s). This open access article is distributed under a CC BY-NC 4.0 license. populations (Naghmouchi et al., 2009). The pod size of the Libyan carob is considered to be medium $(10.89-17.55 \mathrm{~cm})$. Other studies reported that the average pod size may range from 10 to $30 \mathrm{~cm}$, and classified pods size into three categories: long, medium, and short pods (Battle \& Tous, 1997).

The analysis of morphological characteristics of pods and seeds has shown a large phenotypic variation in the Libyan carob. Differences in morphometric traits of carob pods and seeds among Libyan carob populations are primarily caused by genetic factors. Since antiquity, Libyan carob has been propagated naturally by seeds. Thus, carob populations showed a high genetic variation in all morphometric traits.

Furthermore, in this study and similar to other studies, we also observed that the carob showed a high genetic variation in morphologic and agronomic characters among populations of different sites (Batista et al., 1996; Tous, Olarte, Truco, \& Arús, 1992 ; Girolamo et al., 2002), and at the same site(Barracosa et al., 2007).

The Pearson coefficient correlation among morphological parameters of the Libyan carob 
revealed that the characteristics describing the pods showed a positive or negative correlation among each other. On the other hand, there are no correlations among characteristics describing the pods and those describing the seeds except for pod weight. In agreement with our results, many authors have underlined that significant correlations, which were found among characteristics describing pod (El Kahkahi et al., 2014; Elfazazi et al., 2017; Srečec et al., 2016).

The present study reported that analysis of morphological diversity in the Libyan populations of carob showed significant differences among all the analyzed characteristics. Those differences in morphometric traits are caused by genetic factors. The identification of genetic variation in morphological characteristics is necessary for the description of local genetic resources.

\section{REFERENCES}

Albanell, E., Caja, G., \& Plaixats, J. (1991). Characteristics of Spanish carob pods and nutritive value of carob kibbles. Options Mediterraneennes. Serie A: Seminaires Mediterraneens (CIHEAM) .

Barracosa, P., Osorio, J., \& Cravador, A. (2007). Evaluation of fruit and seed diversity and characterization of carob (Ceratonia siliqua L.) cultivars in Algarve region. Scientia Horticulturae, 114(4), 250-257.

Batista, M., Amaral, M., \& Proença Da Cunha, A. (1996). Carob fruits as source of natural oxidant. Paper presented at the Proceedings of the Communication in Third International carob Symposium, Tavira, Portugal.

Battle, I., \& Tous, J. (1997). Carob tree: Ceratonia siliqua L.-Promoting the conservation and use of underutilized and neglected crops. 17: Bioversity International.

Correia, P., \& Martins-Loucao, M. (1994). Preliminary studies on Mycorrrhizae of Ceratonia siliqua L. New York Botanical Gardens: Mycorrhizas in integrated systems from genes to plant development. NY Bronx, 86-88 .

El Kahkahi, R., Zouhair, R., Ait Chitt, M., \& Errakhi, R. (2014). Morocco carob (Ceratonia siliqua L.) populations: Morphological variability of Pods and Kernel. Int. J. Pure App. Biosci, 2(4), 38-47.

Elfazazi, K., Jbilou, M., Assaidi, A., Benbati, M., \& Harrak, H. (2017.) Morphological and Biochemical Variability of Moroccan Carob (Ceratonia siliqua L.) Produced in Beni Mellal Region. Int. J. Pure App. Biosci, 5(4), 14-21 .

El-Zwaam S.M. (1995). El-Jabal El-Akhdar (In Arabic). Garyounis University, Benghazi, Libya

Gharnit, N., Et Mtili, N., Ennabili, A. T., \& Ennabili, A. (2001). Social characterization and exploitation of carob tree (Ceratonia siliqua L.) from Mokrisset and Bab Taza (NW of Morocco). Sci. Lett, 3(2), 1-10 .

Johnson, D. L. (1973). Jabal Al-Akhdar, Cyrenaica: an historical geography of settlement and livelihood: University Press.

Kahkah, E. R ‘.Zouhair, R., Diouri, M., Ait Chitt, M., \& Errakhi, R. (2015). Morphological and biochemical characterization of Morocco carob tree (Ceratonia siliqua L.). Int J Biol Med Res, 6(2), 4946-4952. 
Konaté, I., Filali-Maltouf, A., \& Berraho, E. B. (2007). Diversity analysis of Moroccan carob (" Ceratonia siliqua" L.) accessions using phenotypic traits and RAPD markers .

Lo Gullo, M., \& Salleo, S. (1988). Different strategies of drought resistance in three Mediterranean sclerophyllous trees growing in the same environmental conditions. New phytologist, 108(3), 267-276.

Marakis, S., Kalaitzakis, J., \& Mitrakos, K. (1988). Criteria for recognizing carob tree varieties. Paper presented at the Proceedings of the II International Carob Symposium (P. Fito and Mulet ، eds.) Valencia, Spain.

Naghmouchi, S., Khouja, M., Romero, A., Tous, J., \& Boussaid, M. (2009). Tunisian carob (Ceratonia siliqua L.) populations: Morphological variability of pods and kernel. Scientia Horticulturae, 121(2), 125-130 .

Ramón-Laca, L., \& Mabberley, D. (2004). The ecological status of the carob-tree (Ceratonia siliqua, Leguminosae) in the Mediterranean. Botanical Journal of the Linnean Society, 144(4), 431-436 .

Sharaf, A. T. (1971). Geography of Libya. Alexandria, Egypt, Monsha'at Al Ma'aref, 247 .

Sidina, M. M., El Hansali, M., Wahid, N., Ouatmane, A., Boulli, A., \& Haddioui, A. (2009). Fruit and seed diversity of domesticated carob (Ceratonia siliqua L.) in Morocco. Scientia Horticulturae, 123(1), 110-116.

Srečec, S., Kremer, D., Karlović, K., Peremin Volf, T., Erhatić, R., Augustinović, Z., . . . Dunkić, V. (2016). Comparison of Morphological Characteristics of Carob Tree (Ceratonia siliqua L.) Pods and
Seeds of Populations Collected from Two Distant Croatian Islands: Drvenik Mali and Mali Lošinj. Agriculturae Conspectus Scientificus, 81(1), 61-64 .

Tous, J., Olarte, C., Truco, M., \& Arús, P. (1992). Isozyme polymorphisms in carob cultivars. HortScience, 27(3), 257-258 .

Tous, J., Romero, A., Plana, J., \& Batlle, I. (1996). Current situation of carob plant material. Paper presented at the Proceedings of the III International Carob Symposium. Cabanas-Tavira. Portugal. 


\title{
التباين المورفولوجي في الخروب الليبي (Ceratonia siliqua L.)
}

\author{
عزالدين شعيب محمد علي 1، حسين محمد مصطفي ابراهيم 2" خنساء عمر عبد النبي² \\ إلكلية الزراعة، جامعة عمر الدختار، ليييا

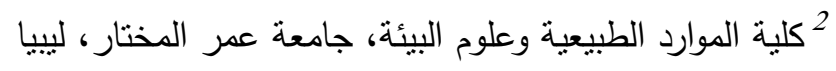 \\ تاريخ الاستلام: 18 يونيو 2019 / ناريخ القبول: 30 يونيو 2019 \\ https://doi.org/10.54172/mjsc.v34i2.77:Doi
}

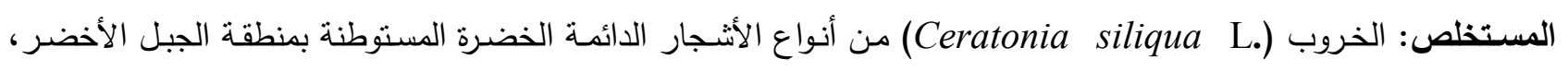

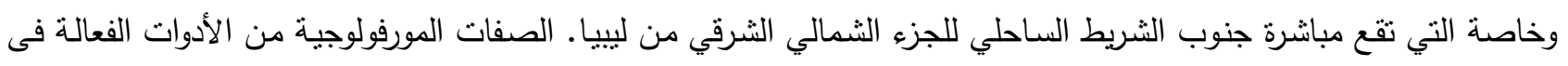

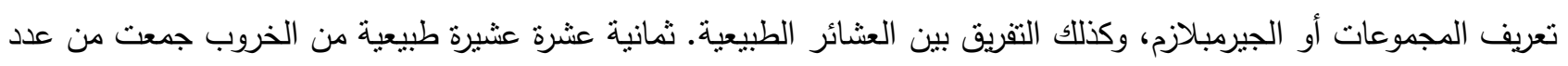

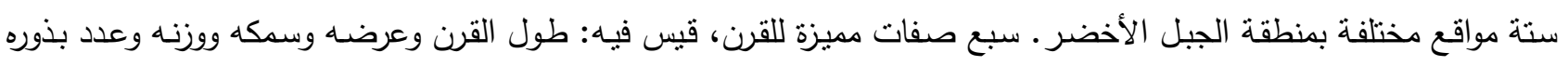

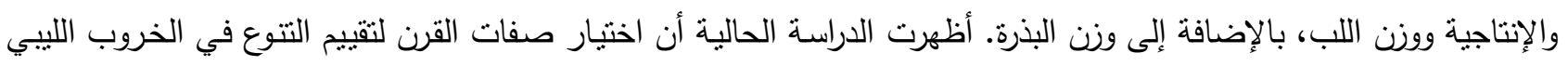

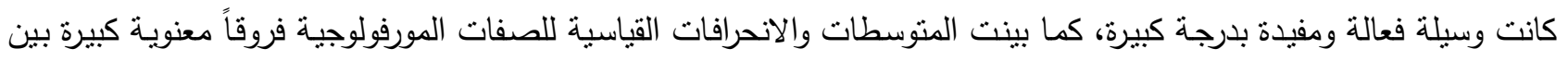

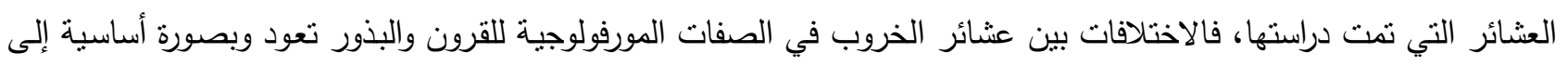
العوامل الوراثية. كما أن قرن الخروب يعد منوسط الحجم ويتراوح ما بين 10.89 إلى 17.55 سم. الكلمات المفتاحية: نبات الخروب؛ Ceratonia siliqua؛ الصفات المورفولوجية؛ التباين الوراثي. 